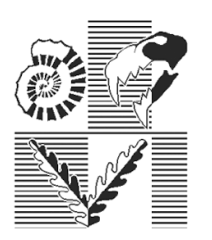

\title{
AM
} EG

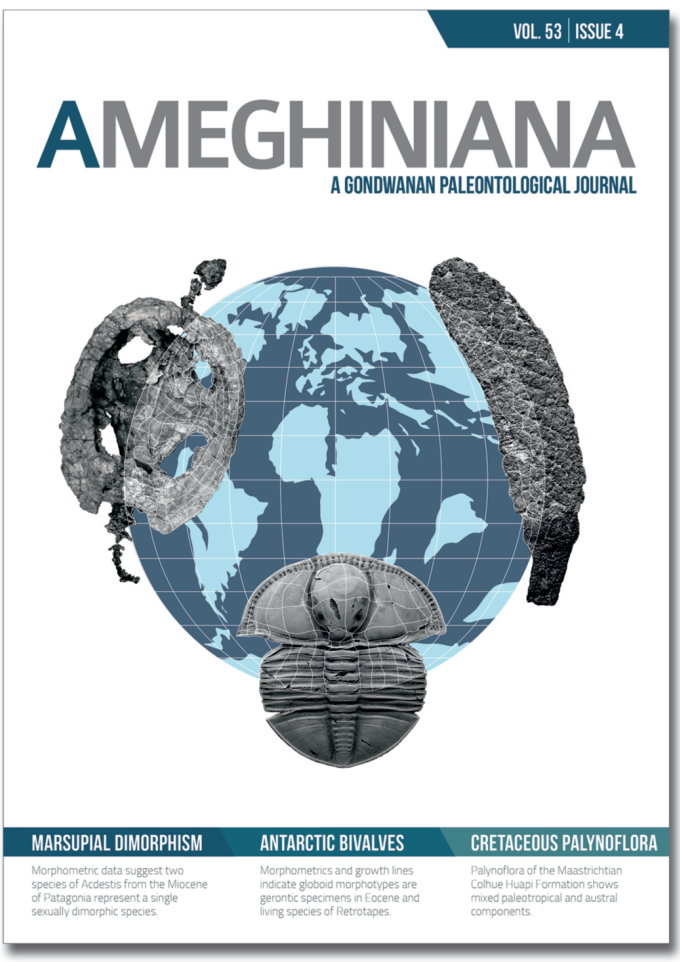

\section{FIRST REPORT OF A MAASTRICHTIAN \\ PALYNOFLORA FROM THE GOLFO SAN JORGE BASIN, CENTRAL PATAGONIA, ARGENTINA}

PATRICIA VALLATI

GABRIEL CASAL

NICOLÁS FOIX

JOSÉ ALLARD

ANDREA DE SOSA TOMAS

MARCOS CALO

Departamento de Geología, Facultad de Ciencias Naturales, Universidad Nacional de la Patagonia San Juan Bosco, Ciudad Universitaria, Km. 4 s/n, 9000 Comodoro Rivadavia, Argentina.

Submitted: August 22 ${ }^{\text {nd }}, 2015$ - Accepted: December 28 ${ }^{\text {th }}, 2015$

To cite this article: Patricia Vallati, Gabriel Casal, Nicolás Foix, José Allard, Andrea De Sosa Tomas, and Marcos Calo (2016). First report of a Maastrichtian palynoflora from the Golfo San Jorge Basin, central Patagonia, Argentina. Ameghiniana 53: 495-505.

To link to this article: http://dx.doi.org/10.5710/AMGH.28.12.2015.2948

PLEASE SCROLL DOWN FOR ARTICLE

Also appearing in this issue:

\section{MARSUPIAL DIMORPHISM}

Morphometric data suggest two species of Acdestis from the Miocene of Patagonia represent a single sexually dimorphic species.

\section{ANTARCTIC BIVALVES}

Morphometrics and growth lines indicate globoid morphotypes are gerontic specimens in Eocene and living species of Retrotapes.
CRETACEOUS PALYNOFLORA

Palynoflora of the Maastrichtian Colhue Huapi Formation shows mixed paleotropical and austral components. 


\title{
FIRST REPORT OF A MAASTRICHTIAN PALYNOFLORA FROM THE GOLFO SAN JORGE BASIN, CENTRAL PATAGONIA, ARGENTINA
}

\author{
PATRICIA VALLATI, GABRIEL CASAL, NICOLÁS FOIX, JOSÉ ALLARD, ANDREA DE SOSA TOMAS, AND MARCOS CALO
}

Departamento de Geología, Facultad de Ciencias Naturales, Universidad Nacional de la Patagonia San Juan Bosco, Ciudad Universitaria, Km. 4 S/n, 9000 Comodoro Rivadavia,Argentina.patricia.vallati@gmail.com; paleogac@yahoo.com.ar;nicofoix@hotmail.com; joseoallard@yahoo.com.ar; adesosatomas@gmail.com; marcos.calo@outlook.com

\begin{abstract}
This paper reports on the biostratigraphic, paleobiogeographic and paleoecologic aspects of palynoflora recovered from sedimentary rocks preliminarily assigned to the Lago Colhué Huapi Formation, in the Golfo San Jorge Basin. The present palynological assemblage includes Maastrichtian marker species of the austral Proteacidites/Nothofagidites Province such as Quadraplanus brossus and Tubulifloridites lilliei. Typical species of the Maastrichtian paleotropical Palmae Province, Buttinia andreeviand Gabonisporis vigourouxii, are also recognized in the palynoflora. These facts indicate the mixed character of the paleoflora and the prevalence of transitional climatic conditions at the paleolatitude of the Chubut Province in the uppermost Cretaceous. The palynoflora composition suggests the local existence of a warm and low energy freshwater body. Key words. Palynology. Maastrichtian. Paleobiogeography. Golfo San Jorge Basin. Chubut.

Resumen. PRIMER REPORTE DE UNA PALINOFLORA MAASTRICHTIANA EN LA CUENCA DEL GOLFO SAN JORGE, PATAGONIA CENTRAL, ARGENTINA. Este artículo informa sobre los aspectos bioestratigráficos, paleobiogeográficos y paleoecológicos de una palinoflora recuperada de rocas sedimentarias asignadas de forma preliminar a la Formación Lago Colhué Huapi, en la Cuenca del Golfo San Jorge. La asociación palinológica incluye especies marcadoras del Maastrichtiano de la Provincia austral Proteacidites/Nothofagidites, como Quadraplanus brossus y Tubulifloridites lilliei. También se reconocen en la palinoflora especies típicas del Maastrichtiano de la Provincia paleotropical Palmae como Buttinia andreevi y Gabonisporis vigourouxii. Estos hechos indican el carácter mixto de la paleoflora y la prevalencia de condiciones climáticas transicionales en la paleolatitud de la Provincia de Chubut. La composición de la palinoflora sugiere la presencia local de un cuerpo de agua dulce templada y de baja energía.
\end{abstract}

Palabras clave. Palinología. Maastrichtiano. Paleoebiogeografía. Cuenca del Golfo San Jorge. Chubut.

THE productive Golfo San Jorge Basin is located in central Patagonia, between the Cañadón Asfalto Basin to the north and the Deseado Massif to the south (Allard et al., 2015). It shows an elongated shape in the $\mathrm{E}-\mathrm{W}$ direction and lies across both Chubut and Santa Cruz provinces. It includes a Late Jurassic to Cenozoic sedimentary filling with Cretaceous units involved in the main basin petroleum systems (Sylwan, 2001).

The palynoflora was recovered from sediments overlying an erosion surface at the top of the Lago Colhué Huapi Formation (Casal et al., 2015) at the headwaters of the Río Chico (designated as the holostratotype of the unit) (Figs. 1, 2.1-3).

Several dinosaur remains, including hadrosaurids and titanosaurids, were identified from the Lago Colhué Huapi
Formation (see references in Casal et al., 2015). Hadrosaurid remains, in particular, were recognized in levels close to the palynological site.

Previous Cretaceous palynological studies in the productive Golfo San Jorge Basin involve both subsurface and exposed units (Van Nieuwenhuise and Ormiston, 1988; Archangelsky et al., 1984, 1994; Vallati, 2013a). Based on the stratigraphic distribution of selected species, Archangelsky et al. (1984) defined several palynological assemblages in the Lower Cretaceous (Berriasian-Aptian) of the basin. The Pozo D-129 Formation, which represents the main hydrocarbon source rock in the basin, includes late Barremian?-early Aptian palynoflora recovered from sediments exposed in the Sierra Silva. Such palynoflora, with primitive angiosperm pollen grains, includes the significant presence 
of the paleotropical marker Tucanopollis crisopolensis (Regali et al., 1974) Regali, 1989 (Vallati, 2013a). A middle Cretaceous microflora was previously reported from the Caleta Olivia Member of the Cañadón Seco Formation (subsurface of the Santa Cruz Province in the southern flank of the basin) by Archangelsky et al. (1994). This assemblage, for which an Albian-Cenomanian age was assigned, included eudicotyledonean angiosperms represented by tricolpate and tricolporoidate pollen grains.

The current study describes a younger palynoflora of biostratigraphic and paleobiogeographic interest. This assemblage represents the first report of a Maastrichtian paIynoflora from the Golfo San Jorge Basin.

\section{GEOLOGICAL SETTING}

The Chubut Group (Lesta and Ferello, 1972), which represents the main sedimentary filling of the basin, is charac- terized by Cretaceous lacustrine and fluvio-lacustrine deposits. In spite of intensive research, few biostratigraphically relevant fossils have been recovered from the Chubut Group in the Golfo San Jorge Basin. Calcareous microfossils reported by Musacchio (in Hechem et al., 1987) and palynological studies performed by Vallati (2013a) suggest a late Barremian?-Aptian age for the basal Pozo D-129 Formation exposed at the Silva ranges.

The Lago Colhué Huapi Formation, widely distributed in the basin, is predominantly composed of reddish mudstones of fluvial origin. According to the position in the basin, the Lago Colhué Huapi Formation overlies the Bajo Barreal Formation and underlies the marine Danian Salamanca Formation or the tuffaceous levels of the Laguna Palacios Formation (Casal et al., 2015). In the upper part of the Lago Colhué Huapi Formation, at the headwaters of the Río Chico, an erosion surface underlies sedimentary rocks in-

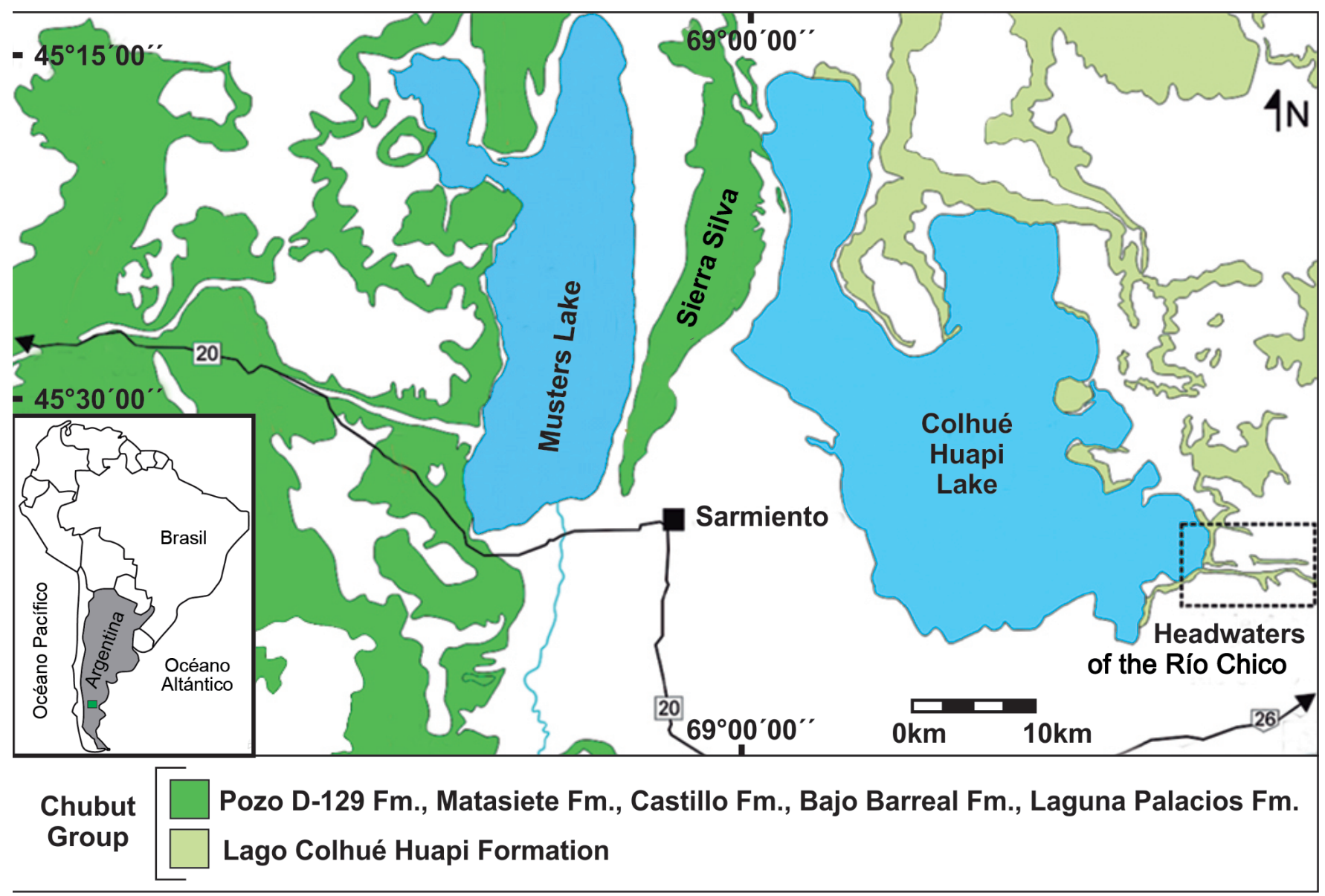

Figure 1. Location map of the studied locality in the Golfo San Jorge Basin (modified from Casal et al., 2015). 


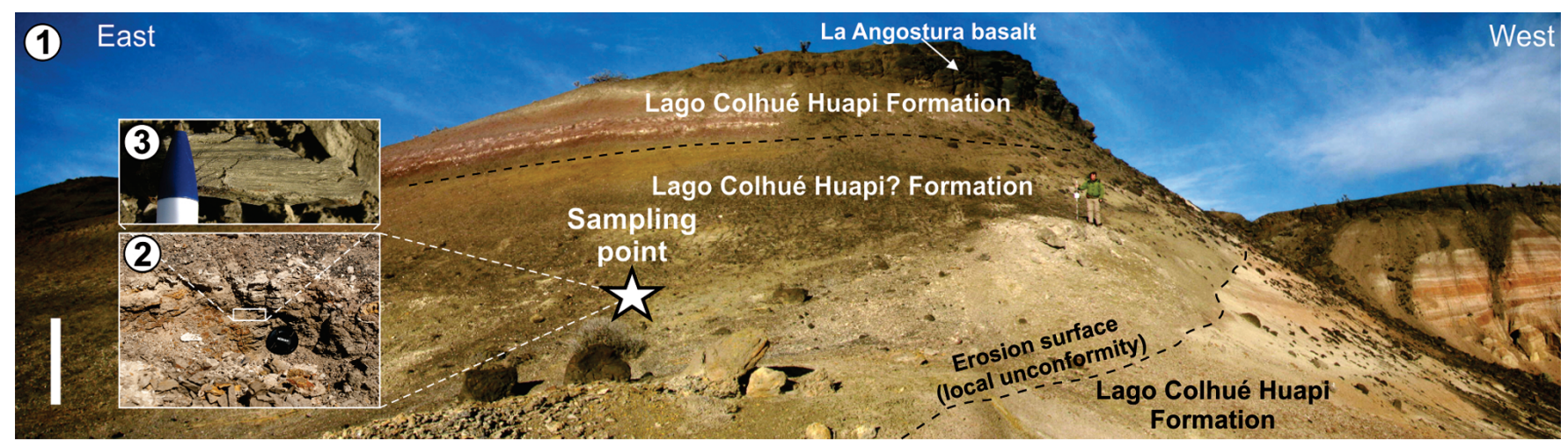

Figure 2. 1, Studied site at the headwaters of the Chico river; 2, Detail of a sampling point; 3 , A fragment of the dark grey laminated siltstone. Scale bar $=3 \mathrm{~m}$

cluding the fertile levels (Lago Colhué Huapi? Formation, Fig. 2.1). Casal et al., (2015) suggested that a comparable stratigraphic interval studied at this same locality could represent the lateral relationships between the uppermost part of the Chubut Group and the Salamanca Formation. At the headwaters of the Río Chico, a basalt flow with a radiometric age of $67.31 \pm 0.55 \mathrm{Ma}$ (La Angostura Basalt) lies on top of the Lago Colhué Huapi Formation (Clyde et al., 2014) (Fig. 2.1).

\section{MATERIALS AND METHODS}

Five fertile samples were recovered from a $30 \mathrm{~cm}$ thick dark grey laminated siltstone. This bed overlies an erosion surface carved in the upper part of the Lago Colhué Huapi Formation, at the headwaters of the Río Chico $\left(45^{\circ} 37^{\prime} \mathrm{S}\right.$, $68^{\circ} 26^{\prime}$ W) (Fig. 2.1-3).

The samples were processed following standard palynological methods including maceration with hydrochloric and hydrofluoric acids for carbonate and silicate removal. A brief oxidation of the residue with nitric acid was performed in order to improve the results. The organic residue was mounted on microscope slides using glycerine jelly. The samples were studied with a Carl Zeiss KF 2 microscope and the microphotographs were obtained with a digital Nikon Coolpix P2 camera at the Biostratigraphic Laboratory of the Universidad Nacional de la Patagonia San Juan Bosco. The relative abundance of palynomorphs mentioned in the analysis of the palynoflora was based on counts of 300 specimens.

The slides are stored in the micropaleontology collection of the UNPSJB (Universidad Nacional de la Patagonia San Juan Bosco) under the initials CR.P.CV. The specimens are cited according to the corresponding slide identification followed by the coordinates of the Vernier Scale in the Zeiss Microscope.

\section{PALYNOLOGICAL RESULTS}

The studied samples yielded fairly well preserved paIynomorphs. Twenty six spore and pollen species were recorded and additional taxa were identified to a genus rank (Appendix). The assemblage includes gymnosperm pollen grains $(44 \%)$, angiosperm pollen grains $(23 \%)$ and spores of Bryophyta, Lycophyta and Pteridophyta (17\%) as well as algal forms (16\%) (Fig. 3). The angiosperms include Proteaceae, with 5 species, as the most diversified taxonomic group.

The species Catinipollis geiseltalensis Krutzsch, 1966 (Fig. 4.11-12), of zygnematalean affinity, was previously recorded in Danian sediments of the Golfo San Jorge Basin by Archangelsky and Zamaloa (1986). Bowman et al. (2014) recorded very similar spores (identified as ?Zygnemataceae spore A) in the uppermost Cretaceous-lowermost Paleogene of the Antarctic Peninsula.

Non vascular plants are mainly represented by the species Zlivisporis reticulatus (Pocock, 1962) Pacltová and Simoncsics, 1970 (Fig. 4.9-10), which presents affinity with the Hepaticae. The Lycophyta include Camarozonosporites cf. ohaiensis (Couper, 1953) Dettmann and Playford, 1968 and the species of Selaginellaceae affinity Ceratosporites equalis Cookson and Dettmann, 1958 (Fig. 4.3). The Filicales are 


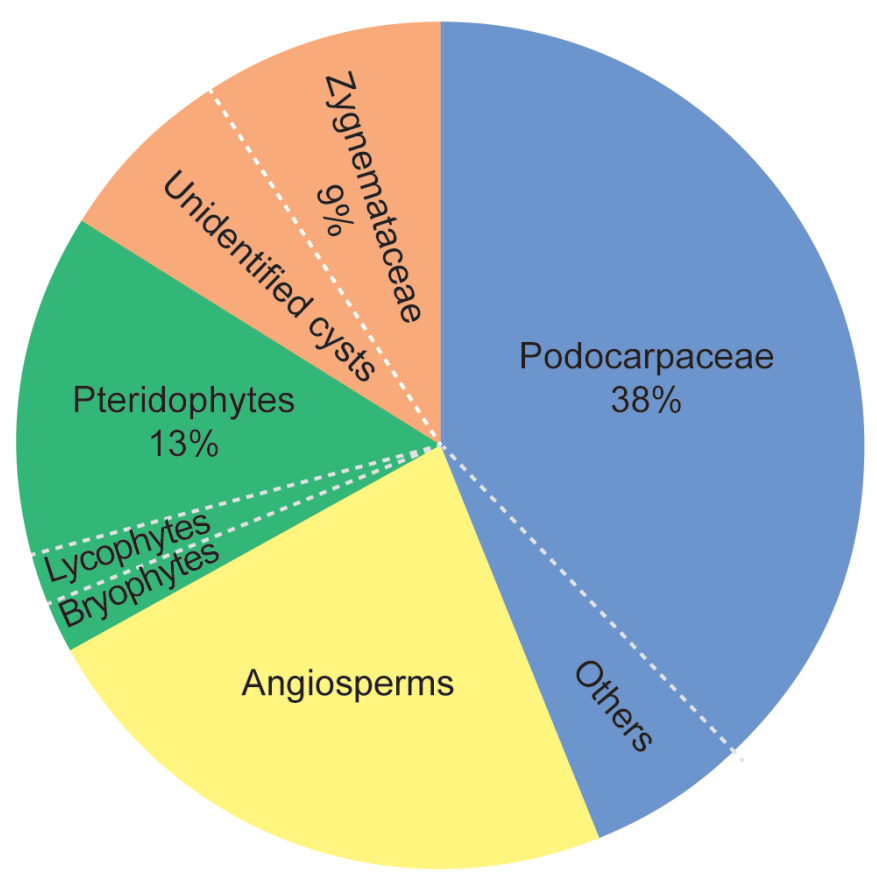

Algae $16 \%$

Angiosperms 23\%

Spores of Bryophytes, Lycophytes, Pteridophytes $17 \%$

Gymnosperms 44\%

Figure 3. Diagram representing the percentages of the different taxonomic groups identified.

mainly represented by Cyatheaceae (Cyathidites sp.), Anemiaceae (Cicatricosisporites spp., Fig. 4.6-7; Ruffordiaspora sp., Fig. 4.8), Gleicheniaceae (Gleicheniidites senonicus Ross, 1949, Fig. 4.1) and the aquatic ferns Salviniales (Azolla spp., Fig. 4.13-15 and Ariadnaesporites micromedusus Stough, 1968, Fig. 4.16).

Conifers dominate the assemblage with abundant bisaccate and trisaccate pollen grains of the Podocarpaceae $(38 \%)$. This family is represented by Microcachryidites antarcticus Cookson, 1947 (Fig. 5.4), Podocarpidites spp. (Fig. 5.7), Rugubivesiculites sp. (Fig. 5.8) and Phyllocladidites mawsonii Cookson, 1947 (Fig. 5.5-6). The latter species shows a close affinity to the pollen of the extant Lagarostrobus franklinii ("Huon pine"). The aforementioned extant taxon is restricted to the wet southwestern Tasmania, Australia, where it is usually found growing along rivers (Bowman et al., 2014). Araucariaceae pollen is mainly represented by Araucariacites australis Cookson, 1947 (Fig. 5.2). Only one specimen of the plicate pollen grain of Gnetophyta affinity, Gnetaceaepollenites barghoornii Lima, 1980 (Fig. 5.3), was recognized in the present palynoflora. Pollen grains of Gnetophyta affinity are more diverse, with several species in other Late Cretaceous palynofloras from northern Patagonia (Vallati, 2013b).

Angiosperms are moderately diversified in the assemblage and mainly include monocolpate pollen grains of Liliaceae (Liliacidites cf. kaitangataensis, Fig. 6.2 and Liliacidites regularis, Fig. 6.1) and triporate and tricolpoidate pollen grains of Proteaceae. The latter family includes Peninsulapollis gillii (Cookson, 1957) Dettmann and Jarzen, 1988 (Fig.6.14), Peninsulapollis truswelliae Dettmann and Jarzen, 1988 (Fig. 6.19), Proteacidites scaboratus Couper, 1960 (Fig. 6.17), Beaupreaidites cf. elegansiformis Cookson, 1950 (Fig. 6.16) and Beaupreaidites orbiculatus Dettmann and Jarzen, 1988 (Fig. 6.15). Peninsulapollis gillii, a species of probable proteaceous affinity, shares some morphological features with Beauprea, which is an extant genus endemic to the mountainous inland regions of New Caledonia (Askin and Baldoni, 1998). The species Beaupreaidites orbiculatus, previously recorded in uppermost Cretaceous sediments from the Otway Basin, southeastern Australia (Dettmann and Jarzen, 1988, 1996), is hereby mentioned in Argentina for the first time.

Spinizonocolpites, which represents the pollen of extant Arecaceae (Nypa-type), is present in the assemblage with specimens including baculae or spinae and exhibiting the hyaline exine described for Spinizonocolpites hialinus Archangelsky and Zamaloa, 1986 from the Bororó and Salamanca formations (Archangelsky and Zamaloa, 1986). The present specimens (Fig. 6.3-5) are only compared to the original species because they include more densely distributed sculptural elements.

Few specimens of Tubulifloridites lilliei (Couper) Farabee and Canright (1986) (Fig. 6.6) were recognized in the palynoflora. This tricolporate pollen grain presents a restricted stratigraphic distribution in the Late Cretaceous of the Southern Hemisphere (New Zealand, Australia, Antarctica and southern South America) (Vajda and Bercovici, 2012; Bowman et al., 2014). Recently, an Asteraceae affinity was suggested for a particular morphological type of this species from the uppermost Cretaceous of the Antarctic Peninsula (Barreda et al., 2015). 

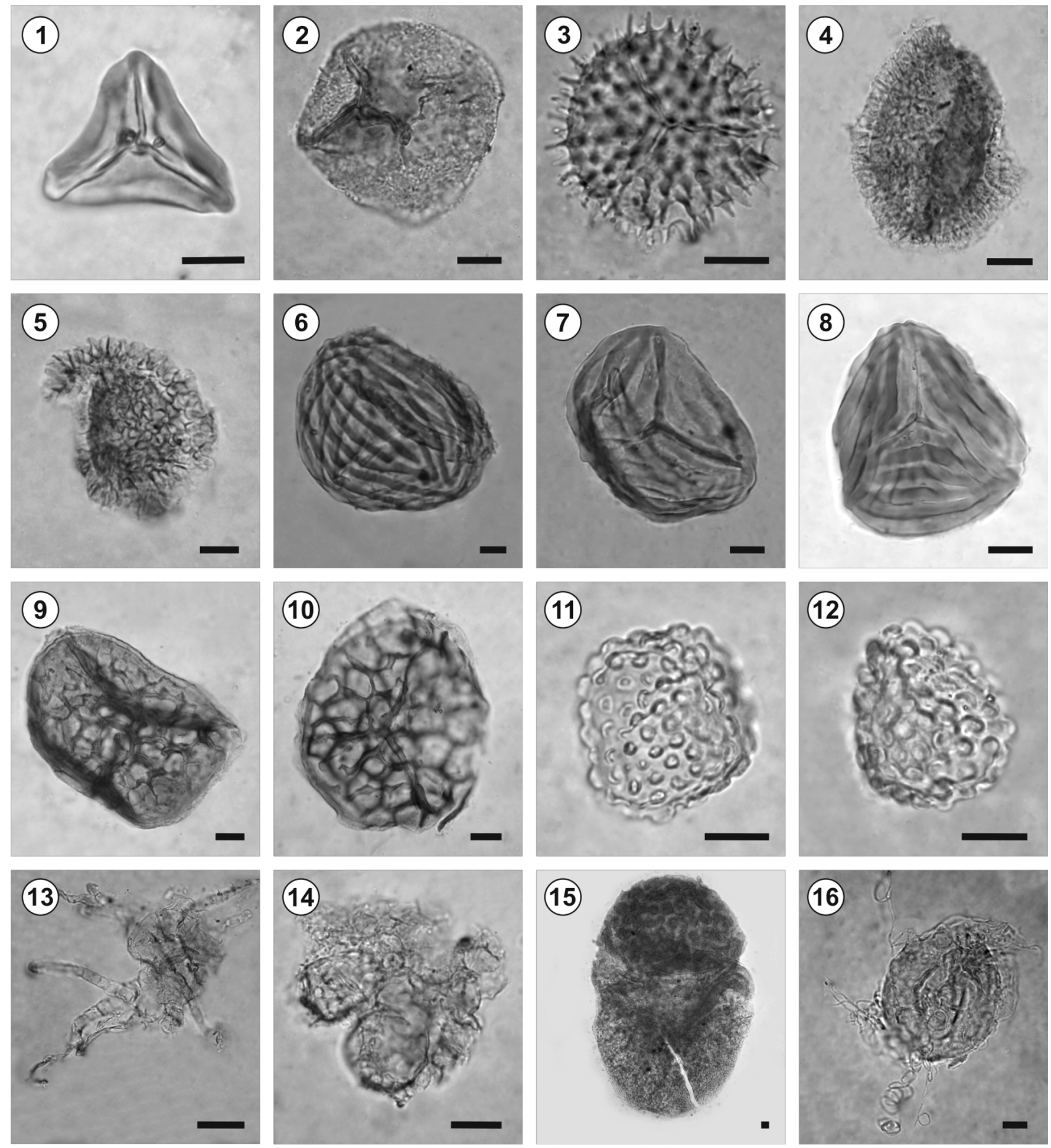

Figure 4. Selected spores and zygospores. 1, Gleicheniidites senonicus, CR.P.CV CH1 15/105; 2, Baculatisporites comaumensis, CR.P.CV CH1d 21/98; 3, Ceratosporites equalis, CR.P.CV CH14 20/90; 4, Gabonisporis vigourouxii, CR.P.CV CH1c 4/94; 5, Gabonisporis vigourouxii, CR.P.CV CH1c 10/94; 6, Cicatricosisporites sp. 1, CR.P.CV CH1d 18/95.5; 7, Cicatricosisporites sp. 2, CR.P.CV CH1d 10/95; 8, Ruffordiaspora sp., CR.P.CV CH2a 15/100; 9, Zlivisporis reticulatus, CR.P.CV CH14-19/85; 10, Zlivisporis reticulatus, CR.P.CV CH2a 22/105; 11, Catinipollis geiseltalensis, CR.P.CV CH1e 15/105; 12, Catinipollis geiseltalensis, CR.P.CV CH1b 5/93; 13, Azolla sp.1, microspore massula with septate glochidia, CR.P.CV CH2b 16/109; 14, Azolla sp. 2, microspore massula fragment, CR.P.CV CH2c 22/102; 15, Azolla, megaspore apparatus, CR.P.CV CH14m 11/92; 16, Ariadnaesporites micromedusus, microspore, CR.P.CV CHo 18/96.5. Scale bars $=10 \mu \mathrm{m}$. 


\section{BIOSTRATIGRAPHY AND PALEOBIOGEOGRAPHY}

The palynoflora yields Quadraplanus brossus Stover and Partridge, 1973, and Tubulifloridites lilliei (Figs. 6.9-13 and 6.6, respectively), which are key Maastrichtian species of the southern Proteacidites/Nothofagidites Province (Herngreen et al., 1996). Both species became extinct at the Cretaceous/Paleogene boundary in Australia, New Zealand and Seymour Island (Antarctica) (Vajda and Bercovici, 2012, 2014). Quadraplanus brossus, particularly, shows a stratigraphic distribution restricted to the upper Maastrichtian of sections also rich in dinoflagellates in the Southern Hemisphere (Raine and Schiøler, 2012; Vajda and Bercovici,
2012). The assemblage also includes some species characteristic of the Upper Cretaceous Palmae Province of Herngreen et al. (1996) such as the zonosulcate taxa Proxapertites and Spinizonocolpites and the typical Maastrichtian species Buttinia andreevi Boltenhagen, 1967 (Fig. 6.8) and Gabonisporis vigorouxii Boltenhagen, 1967 (Fig. 4.4). This supports both the Maastrichtian age of the palynoflora and the location of the Patagonian Region in a Late Cretaceous Transitional (Mixed) Province (Vajda and Bercovici, 2012, 2014). As suggested by the presence of several species of the tropical pollen grains Tucanopollis and Afropollis in Cretaceous Patagonian sediments (Vallati, 2006, 2013a), Pata-
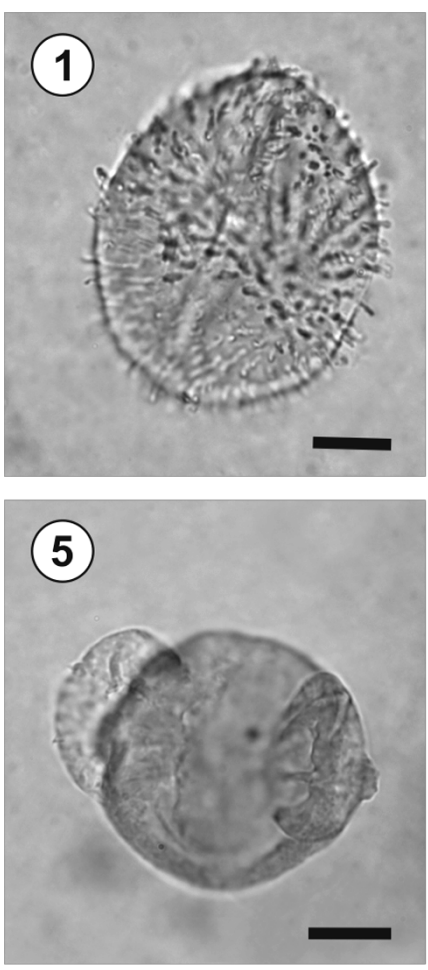
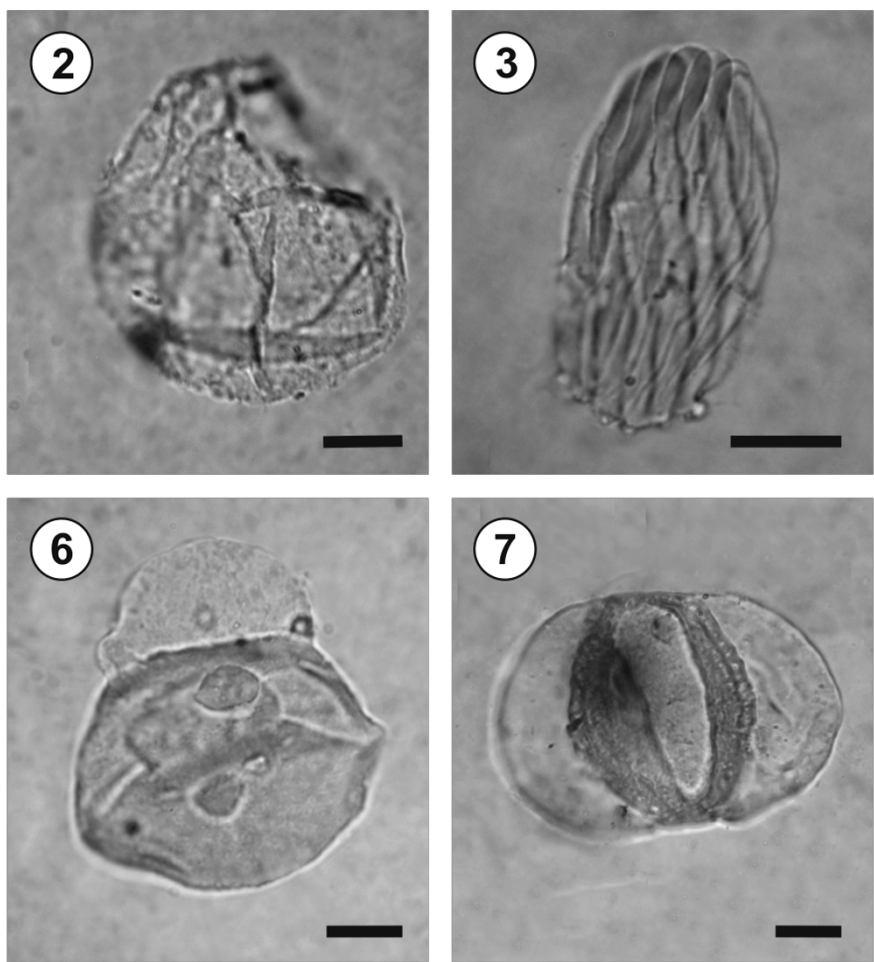
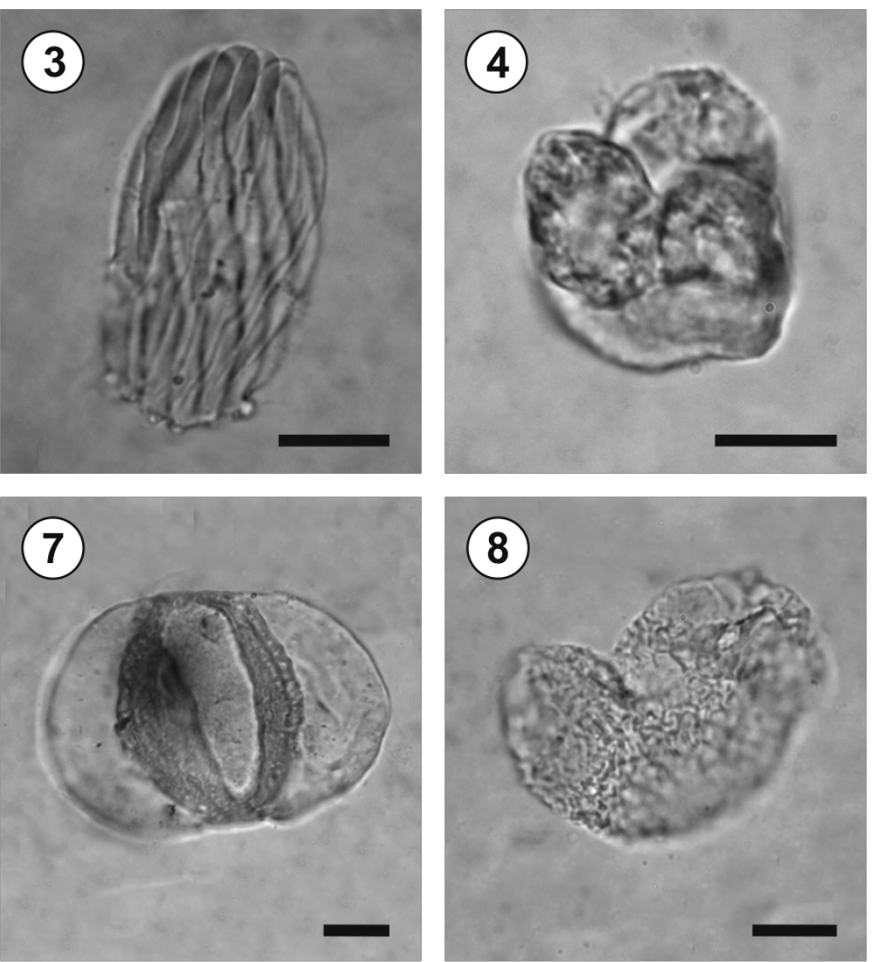

Figure 5. Selected gymnosperm pollen grains. 1, Echimonocolpites sp., CR.P.CV CH1d 15/95; 2, Araucariacites australis, CR.P.CV CH2j 12/98; 3, Gnetaceaepollenites barghoornii, CR.P.CV CHw 12.5/115; 4, Microcachryidites antarcticus, CR.P.CV CH14 99/19.2; 5, Phyllocladidites mawsonii, CR.P.CV CHy 11/90; 6, Phyllocladidites mawsonii, CR.P.CV Ch2 16/102; 7, Podocarpidites sp., CR.P.CV CH1a 12/94; 8, Rugubivesiculites sp., CR.P.CV CH1p 117/105. Scale bars $=10 \mu \mathrm{m}$.

Figure 6. Selected angiosperm pollen grains. 1, Liliacidites regularis, CR.P.CV CH2s 16.5/99; 2, Liliacidites cf. kaitangataensis, CR.P.CV CH2j 20/105; 3, Spinizonocopites cf. hialinus, CR.P.CV CH1d 21/92; 4, Spinizonocopites cf. hialinus, CR.P.CV CHx 24/100; 5, Spinizonocopites cf. hialinus, CR.P.CV CH 18/108; 6, Tubulifloridites lilliei, CR.P.CV CH1e 11/94; 7, Proxapertites sp., CR.P.CV CH2m 23/105; 8, Buttinia andreevi, CR.P.CV CH1 8/95; 9, Quadraplanus brossus, CR.P.CV CH1x 14/94; 10, Quadraplanus brossus, CR.P.CV CH2m 20/94; 11, Quadraplanus brossus, detail of the sculpture in the specimen of Fig. 10; 12, Quadraplanus brossus, individual grain, CR.P.CV CH2s 15/102; 13, Quadraplanus brossus, individual grain, CR.P.CV CH2s 12/95; 14, Peninsulapollis gillii, CR.P.CV CH2s 11/100; 15, Beaupreaidites orbiculatus, CR.P.CV CH2 5/107; 16, Beaupreaidites cf. elegansiformis, CR.P.CV CHx 16/100; 17, Proteacidites scaboratus, CR.P.CV CHx 20/104; 18, Proteacidites cf. scaboratus, CR.P.CV CH2s 18/105; 19, Peninsulapollis truswelliae, CR.P.CV CH2s 8/96; 20, Tricolpites sp., pollen grain mass, CR.P.CV CH1b 6/95. Scale bars $=10 \mu \mathrm{m}$. 

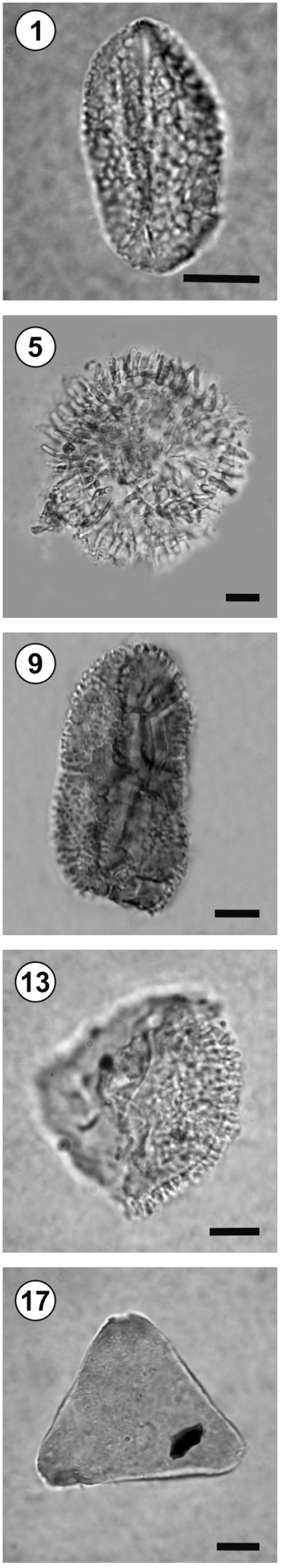
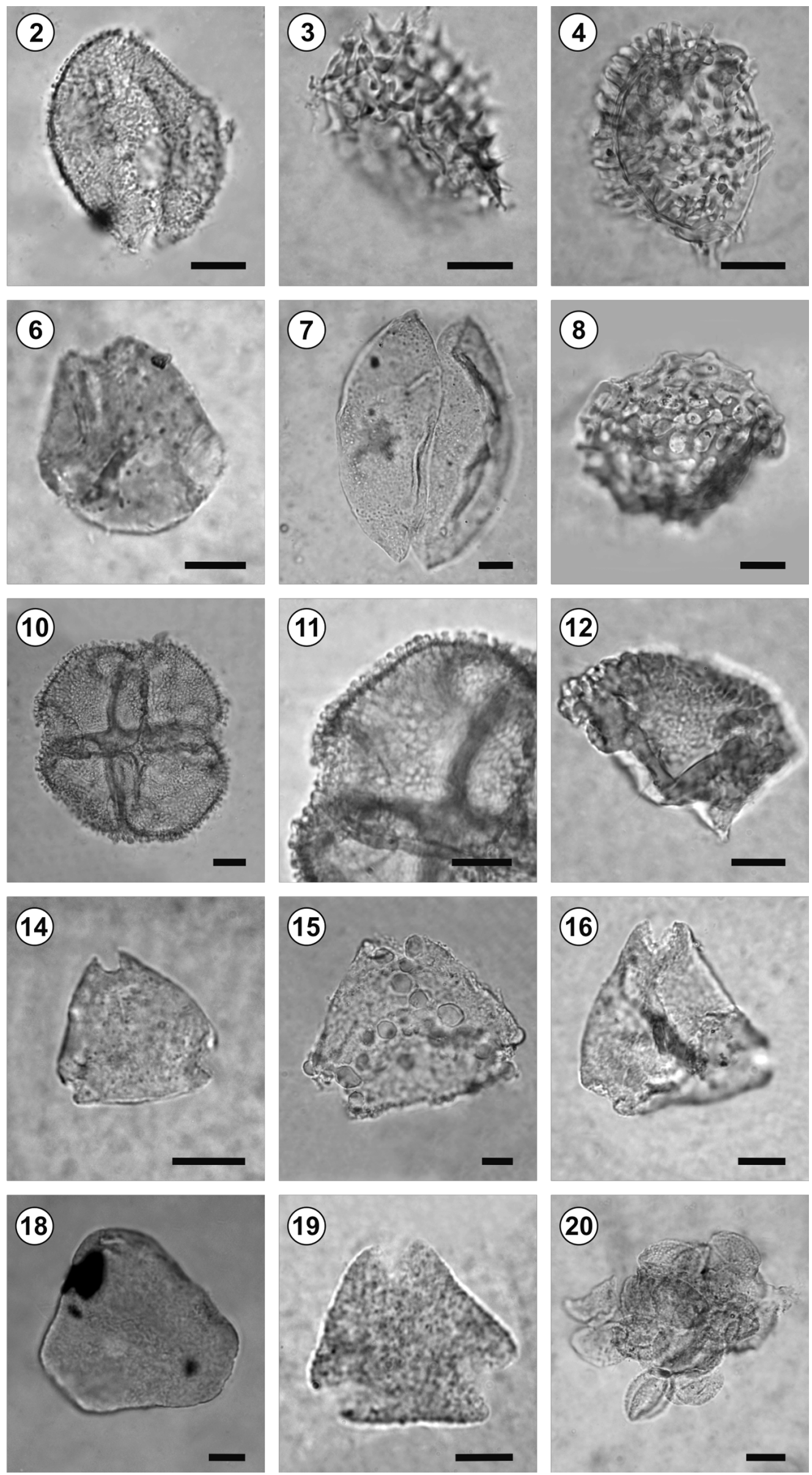

(19)

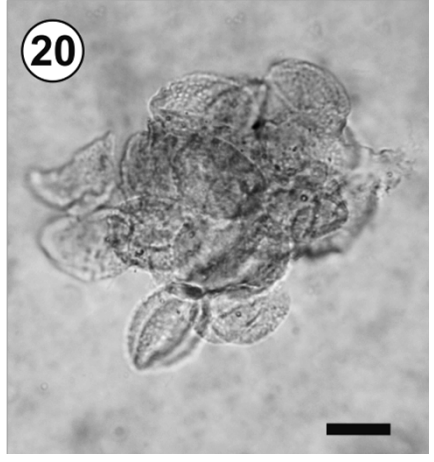


gonia occupied this Transitional Province at least since Aptian times.

The angiosperm family Proteaceae is represented by several species in the studied palynoflora. This extant Gondwanan group of plants has a significant fossil record in Australia, New Zealand and the Antarctic Peninsula (Wanntorp et al., 2011). The proteaceous and species of probable proteaceous affinity recognized in the present assemblage include several taxa initially described for the uppermost Cretaceous strata of southeastern Australia and the Antarctic Peninsula (Dettmann and Jarzen, 1988).

Nothofagidites, a characteristic taxon of the austral Proteacidites/Nothofagidites Province, was not recognized in the studied assemblage. The oldest record of this taxon in Patagonia was reported from the middle Maastrichtian of the Jagüel Formation, in the Neuquén Basin, by Romero (1973). The absence of this taxon could be due to the palynoflora predating the incoming of Nothofagidites in the Golfo San Jorge Basin or to environmental conditions.

The studied assemblage bears more similarities to the Maastrichtian Patagonian palynofloras from the lower Lefipán Formation in Chubut Province (Baldoni, 1992; Baldoni and Askin, 1993; Barreda et al., 2012) and the Monte Chico Formation in Santa Cruz Province (Povilauskas, 2011, 2012, 2013). The present palynoflora shares the marker Quadraplanus brossus and the species Baculatisporites comaumensis, Ceratosporites equalis, Araucariacites australis, Phyllocladidites mawsonii, Microcachryidites antarcticus, Ericipites scabratus and Peninsulapollis gillii with both abovementioned assemblages. Additionally, it shares the marker Tubulifloridites lilliei with the lower Lefipán Formation.

Regarding Maastrichtian assemblages from other regions in Argentina, the Ciénaga de Río Huaco Formation in San Juan Province includes a mixed palynoflora with some spores and pollen grains characteristic of the paleotropical Province (Limarino et al., 2000).

\section{PALEOENVIRONMENTAL CONSIDERATIONS}

The presence of frequent monospecific masses of spores and pollen grains in the assemblage (Fig. 6.20) is probably indicative of the autochthonous nature of some of its components and of a low energy environment at the time of deposition.

Aquatic fern spores (Azolla spp.; Ariadnaesporites mi- cromedusus) together with lycophytes and algal elements suggest the local existence of a freshwater body and a warm climate. Particularly, zygospores of the green filamentous algae Zygnemataceae such as Catinipollis geiseltalensis Krutzsch, 1966 imply warm, shallow and low energy freshwaters (Scafati et al., 2009; Bowman et al., 2014).

Terrestrial bryophytes (Zlivisporis reticulatus) and ferns of Anemiaceae (Cicatricosisporites, Ruffordiaspora), Cyatheaceae (Cyathidites) and Selaginellaceae (Ceratosporites equalis) represent the local vegetation that grew around the freshwater body. Proteaceae and Podocarpaceae probably occupied the humid riverbanks under a temperate warm climate. Bowman et al. (2014) drew attention to the fact that the abundance of wind-pollinated conifers in comparison to that of Proteaceae is probably related to their different pollination mechanisms. Palmae-type pollen grains (Spinizonocolpites cf. hialinus Archangelsky and Zamaloa, 1986, Fig. 6.3-5) suggest the presence of Nypa-type palms, which currently inhabit warm marine coastal environments (Scafati et al., 2009).

In central Patagonia, similar freshwater paleocommunities were reported from the Danian Cerro Bororó Formation (Scafati et al., 2009) and from the Late Cretaceous La Colonia Formation (Cúneo et al., 2014).

\section{CONCLUSIONS}

The palynoflora from the studied levels at the headwaters of the Río Chico, in the Golfo San Jorge Basin, includes austral Maastrichtian key species such as Quadraplanus brossus and Tubulifloridites lilliei. The assemblage is also typified by paleotropical Maastrichtian markers such as Buttinia andreevi and Gabonisporis vigourouxii. All abovementioned taxa characterize late Maastrichtian assemblages and become extinct at the Cretaceous/Paleogene boundary thus suggesting a late Maastrichtian age for the studied palynoflora.

The species Buttinia andreevi and Beaupreaidites orbiculatus are recorded for the first time in Argentina.

The co-occurrence of key species from both paleotropical and austral Provinces corroborates the presence of the mixed flora that characterizes the Transitional Upper Cretaceous Floristic Province of southern South America (Vajda and Bercovici, 2012) at the latitude of the studied locality.

The recovered palynoflora suggests local depositional 
conditions related to a low energy freshwater body and a warm climate. The presence of pollen grains of the marine coastal Nypa-type Arecaceae such as Spinizonocolpites together with Proxapertites (Fig. 5.7) probably indicates the close proximity of a shoreline.

\section{ACKNOWLEDGMENTS}

This paper is dedicated to the memory of our professor and colleague Eduardo Musacchio. We thank Antonio Perujo (†), Héctor Martínez, C. Martínez and Luis Insúa, landowners at the headwaters of the Chico river. Marcelo Luna is acknowledged for fieldwork assistance. The authors would like to thank the artwork editor, Alejandro Otero, the Scientific Editor, Viviana Barreda, and two anonymous reviewers for their suggestions and comments that greatly improved the manuscript.

\section{REFERENCES}

Allard, J.O., Paredes, J.M., Foix, N., and Giacosa, R.E. 2015. Conexión Cretácica entre las cuencas del golfo San Jorge y Cañadón Asfalto (Patagonia): paleogeografía, implicancias tectonoestratigráficas y su potencial en la exploración de hidrocarburos. Revista de la Asociación Geológica Argentina 72: 25-41.

Archangelsky, S., Baldoni, A., Gamerro, J.C., and Seiler, J. 1984. Palinología estratigráfica del Cretácico de Argentina austral III. Distribución de las especies y conclusiones. Ameghiniana 21: 15-33.

Archangelsky, S., Bellosi, E.S., Jalfin, G.A., and Perrot, C. 1994. Palynology and alluvial facies from the mid-Cretaceous of Patagonia, subsurface of San Jorge Basin, Argentina. Cretaceous Research 15: 127-142.

Archangelsky, S., and Zamaloa, M.C. 1986. Nuevas descripciones palinológicas de las formaciones Salamanca y Bororo, Paleoceno de Chubut (República Argentina). Ameghiniana 23: 35-46.

Askin, R.A., and Baldoni, A.M. 1998. The Santonian through Paleogene record of Proteaceae in the southern South AmericaAntarctic Peninsula Region. Australian Systematic Botany 11: 373-390.

Baldoni, A.M. 1992. Palynology of the lower Lefipán Formation (Upper Cretaceous) of Barranca de los Perros, Chubut Province, Argentina. Part I. Cryptogam spores and gymnosperm pollen. Palynology 16: 117-136.

Baldoni, A.M., and Askin, R.A. 1993. Palynology of the lower Lefipán Formation (Upper Cretaceous) of Barranca de los Perros, Chubut Province, Argentina. Part II. Angiosperm pollen and discussion. Palynology 17: 241-264.

Barreda, V., Cúneo, R., Wilf, P., Currano, E.D., Scasso, R.A., and Brinkhuis, H. 2012. Cretaceous/Paleogene floral turnover in Patagonia: drop in diversity, low extinction, and a Classopollis Spike. Plos One 7: e52455. doi:10.1371/journal.pone.0052455

Barreda, V., Palazzesi, L., Tellería, M.C., Olivero, E.B., Rainee, J.I., and Forest, F. 2015. Early evolution of the angiosperm clade Asteraceae in the Cretaceous of Antarctica. Proceedings of the National Academy of Sciences 112: 10989-10994. doi:10.1073/ pnas. 1423653112

Boltenhagen, E. 1967. Spores et pollen du Crétacé Supérieur du Gabon. Pollen et Spores 9: 335-355.

Bowman, V., Francis, J.E., Askin, R., Riding, J.B., and Swindles G.T. 2014. Latest Cretaceous-earliest Paleogene vegetation and climate change at the high southern latitudes: palynological evidence from Seymour Island, Antarctic Peninsula. Palaeo- geography, Palaeoclimatology, Palaeoecology 408: 26-47.

Casal, G., Allard, J., and Foix, N. 2015. Análisis estratigráfico y paleontológico del Cretácico Superior en la Cuenca del Golfo San Jorge: nueva unidad litoestratigráfica para el Grupo Chubut. Revista de la Asociación Geológica Argentina 72: 81-99.

Clyde, W.C., Wilf, P., Iglesias, A., Slingerland, R.L., Barnum, T., Bijl, P.K., Bralower, T.J., Brinkhuis, H., Comer, E.E., Huber, B.T., Ibañez-Mejía, M., Jicha, B.R., Krause, M., Schueth, J.D., Singer, B.S., Raigemborn, M.S., Schmitz, M.D., Sluijs, A., and Zamaloa, M. del C. 2014. New age constraints for the Salamanca Formation and lower Río Chico Group in the western San Jorge Basin, Patagonia, Argentina: correlations. Geological Society of American Bulletin 126: 289-306. doi:10.1130/B30915.1

Cookson, I.C. 1947. Plant microfossils from the lignites of the Kerguelen Archipelago. British and New Zealand Antarctic Research Expedition, 1929-1931. Reports Series A 2: 129-142.

Cookson, I.C., and Dettmann, M.E. 1958. Some trilete spores from Upper Mesozoic deposits in the eastern Australian region. Proceedings of the Royal Society of Victoria 70: 95-128.

Cookson, I.C., and Dettmann, M.E. 1959. On Schizosporis, a new form genus from Australian Cretaceous deposits. Micropaleontology 5: 213-216.

Cúneo, R., Gandolfo, M.A., Zamaloa, M.C., and Hermsen, E. 2014. Late Cretaceous aquatic plant world in Patagonia, Argentina. Plos One 9: e104749. doi:10.1371/journal.pone.0104749

Dettmann, M.E., and Jarzen, D.M. 1988. Angiosperm pollen from uppermost Cretaceous strata of southeastern Australia and the Antarctic Peninsula. Association of Australasian Palaeontologists 5: 217-237.

Dettmann, M.E., and Jarzen, D.M. 1996. Pollen of proteaceous-type from latest Cretaceous sediments, southeastern Australia. Alcheringa: An Australasian Journal of Palaeontology 20: 103-160.

Dettmann, M.E., and Playford, G. 1968. Taxonomy of some Cretaceous spores and pollen grains from eastern Australia. Proceedings of the Royal Society of Victoria 81: 69-94.

Farabee, M.J., and Canright, J.E. 1986. Stratigraphic palynology of the lower part of the Lance Formation (Maastrichtian) of Wyoming. Palaeontographica 199: 1-89.

Harris, W.K. 1965. Basal Tertiary microfloras from the Princetown area, Victoria, Australia. Palaeontographica, Abteilung B 15: $75-$ 106.

Hechem, J.J., Figari, E.G., and Musacchio, E.A. 1987. Hallazgo de la Formación Pozo Diadema 129 en superficie: información estratigráfica y paleontológica en la Cuenca del Golfo San Jorge. Petrotecnia 28: 13-15.

Herngreen, G.F.W., Kedves, M., Rovnina, L.V., and Smirnova, S.B. 1996. Cretaceous palynofloral provinces: A review. In: J. Jansonius, and D.C. McGregor (Eds.), Palynology: Principles and applications. American Association of Stratigraphic Palynologists Foundation, Salt Lake City, p. 1157-1188.

Krutzsch, W. 1966. Zur Kenntnis der praequartaeren periporaten Pollenformen. Geologie Beihefte 15: 16-71.

Lesta, P., and Ferello, R. 1972. Región extraandina del Chubut y norte de Santa Cruz. In: A.F. Leanza (Ed.), Geología Regional Argentina. Academia Nacional de Ciencias, p. 601-654.

Limarino, C., Net, L., Gutierrez, P., Barreda, V., Caselli, A., and Ballent, S. 2000. Definición litoestratigráfica de la Formación Ciénaga de Río Huaco (Cretácico Superior), Precordillera Central, San Juan, Argentina. Revista de la Asociación Geológica Argentina 55: 83-99.

Pacltová, B., and Simoncsics, P. 1970. New types of spores (genera and species) from the Bohemian Miocene. Paläontologische Abhandlungen B (Paläobotanik) 3: 599-617. 
Paden Phillips, P., and Felix C.J. 1971. A study of Lower and Middle Cretaceous spores and pollen from Southeastern United States. I. Spores. Pollen et Spores 13: 279-348.

Potonié, R., 1956. Synopsis der Gattungen der Sporae dispersae. I. Teil: Sporites. Beihefte zum Geologischen Jahrbuch 23. Hannover, $103 \mathrm{p}$.

Povilauskas, L. 2011. Palinología de la Formación Monte Chico (Cretácico Tardío) de la Provincia de Santa Cruz, Argentina: Esporas. Revista Brasileira de Paleontología 14: 255-268. doi:10.4072/rbp.2011.3.05

Povilauskas, L. 2012. Palinología de la Formación Monte Chico (Cretácico Tardío) de la Provincia de Santa Cruz, Argentina: Gimnospermas. Revista Brasileira de Paleontología 15: 85-94. doi:10.4072/rbp.2012.1.07

Povilauskas, L. 2013. Palinología de la Formación Monte Chico (Cretácico Tardío) de la Provincia de Santa Cruz, Argentina: Angiospermas. Revista Brasileira de Paleontología 16:115-126. doi:10.4072/rbp.2013.1.09

Raine, J.I., and Schiøler, P. 2012. Upper Cretaceous biostratigraphy of Maui-4 and Tane-1, Taranaki Basin. GNS Science Report, 29 p.

Regali, M.S.P. 1989. Tucanopollis, a new genus of early angiosperms. Boletim Técnico Petrobras 3: 395-402.

Romero, E.J. 1973. Polen fósil de Nothofagus (Nothofagidites) del Cretácico y Paleoceno de Patagonia. Revista del Museo de La Plata 7: 291-303.

Ross, N.E. 1949. Investigations of the Senonian of the Kristianstad district, S. Sweden. I. On a Cretaceous pollen and spore bearing clay deposit of Scania. Bulletin of the Geological Institution of the University of Upsala 34: 25-43.

Scafati, L., Melendi, D.L., and Volkheimer, W. 2009. A Danian subtropical lacustrine palynobiota from South America (Bororó Formation, San Jorge Basin, Patagonia-Argentina). Geologica Acta 7: 35-61. doi: 10.1344/105.000000270

Stough, J.B. 1968. Palynomorphs from South America. Part 1. New Late Cretaceous palynomorphs from southern South America. The University of Kansas Paleontological Contribution Papers 32 $1-8$.

Stover, L.E., and Partridge, A.D. 1973. Tertiary and Late Cretaceous spores and pollen from the Gippsland Basin, southeastern Australia. Proceedings of the Royal Society of Victoria 85: 237-286.

Sylwan, C.A. 2001. Geology of the Golfo San Jorge Basin, Argentina. Journal of Iberian Geology 27: 123-157.

Vajda, V., and Bercovici, A. 2012. Pollen and Spore stratigraphy of the Cretaceous-Paleogene Southern Hemisphere. Journal of Stratigraphy 36: 153-164.

Vajda, V., and Bercovici, A. 2014. The global vegetation pattern across the Cretaceous-Paleogene mass extinction interval: $A$ template for other extinction events. Global and Planetary Change 122: 29-49.

Vallati, P. 2006. Las primeras angiospermas en el Cretácico de la Cuenca Neuquina (centro-oeste de Argentina): aspectos geológicos relacionados. Revista Brasileira de Paleontologia 9: 8392.

Vallati, P. 2013a. A mid Cretaceous palynoflora with Tucanopollis crisopolensis from D-129 Formation, San Jorge Gulf Basin, Argentina. Revista Brasileira de Paleontologia 16: 237-244. doi: 10.4072/rbp.2013.2.06

Vallati, P. 2013b. Paleotropical pollen grains from the Neuquén Group, Patagonia, Argentina. Carnets de Géologie [Notebooks on Geology] - Letter 2013/05 (CG2013_L05): 273-279.

Van Nieuwenhuise, D.S., and Ormiston, A.R. 1988. A model for the origen of source-rich lacustrine facies, San Jorge Gulf Basin, Argentina. $1^{e r}$ Congreso Nacional de Exploración de Hidrocarburos
(Mar del Plata), Actas: 852-871.

Wanntorp, L., Vajda, V., and Raine, J.I. 2011. Past diversity of Proteaceae on subantarctic Campbell Island, a remote outpost of Gondwana. Cretaceous Research 32: 357-367.

\section{APPENDIX \\ Taxonomic list of identified taxa}

Zygnemataceae (filamentous green algae)

Catinipollis geiseltalensis Krutzsch, 1966 (Figure 4.11,12)

Ovoidites sp.

Schizosporis reticulatus Cookson and Dettmann, 1959

\section{Bryophyta}

Zlivisporis reticulatus (Pocock 1962) Pacltová and Simoncsics, 1970 (Figure 4.9,10)

\section{Lycophyta}

Camarozonosporites cf. ohaiensis (Couper, 1953) Dettmann and Playford, 1968

Ceratosporites equalis Cookson and Dettmann, 1958 (Figure 4.3)

\section{Pteridophyta (Filicales)}

Ariadnaesporites micromedusus Stough, 1968 (Figure 4.16)

Azolla sp. 1 massula (Figure 4.13)

Azolla sp. 2 massula (Figure 4.14)

Azolla megaspore apparatus (Figure 4.15)

Baculatisporites comaumensis (Cookson 1953) Potonie, 1956

(Figure 4.2)

Cicatricosisporites sp. 1(Figure 4.6)

Cicatricosisporites sp. 2 (Figure 4.7)

Ruffordiasporasp. (Figure 4.8)

Cyathidites sp.

Gabonisporis vigourouxii Boltenhagen, 1967 (Figure 4.4,5)

Gleicheniidites senonicus Ross, 1949 (Figure 4.1)

\section{Spore of uncertain botanical affinity}

Interulobites intraverrucatus (Brenner, 1963) Paden Phillips, 1971

\section{Gymnosperms}

Araucariacites australis Cookson, 1947 (Figure 5.2)

Classopollis sp.

Cycadopites sp.

Echimonocolpites sp. (Figure 5.1)

Gnetaceaepollenites barghoornii Lima, 1980 (Figure 5.3)

Microcachryidites antarcticus Cookson, 1947 (Figure 5.4)

Phyllocladidites mawsonii Cookson, 1947 ex Couper, 1953 (Figure $5.5,6)$

Podocarpidites spp. (Figure 5.7)

Rugubivesiculites sp. (Figure 5.8)

\section{Angiosperms}

Buttinia andreevi Boltenhagen, 1967 (Figure 6.8)

Beaupreaidites cf. elegansiformis Cookson, 1950 (Figure 6.16)

Beaupreaidites orbiculatus Dettmann and Jarzen, 1988 (Figure 6.15)

Ericipites scabratus Harris, 1965

Liliacidites cf. kaitangataensis Couper, 1953 (Figure 6.2) 
Liliacidites regularis Archangelsky, 1973 (Figure 6.1)

Peninsulapollis gillii (Cookson, 1957) Dettmann and Jarzen, 1988

(Figure 6.14)

Peninsulapollis truswelliae Dettmann and Jarzen, 1988 (Figure 6.19)

Proteacidites scaboratus Couper, 1960 (Figure 6.17)

Proteacidites cf. scaboratus Couper, 1960 (Figure 6.18)

Proxapertites sp. (Figure 6.7)

Quadraplanus brossus Stover and Partridge, 1973 (Figure 6.9-13)

Spinizonocolpites cf. hialinus Archangelsky and Zamaloa, 1986

(Figure 6.3-5)

Tricolpites sp. (Figure 6.20)

Tubulifloridites lilliei (Couper) Farabee and Canright, 1986 (Figure 6.6)

doi: 10.5710/AMGH.28.12.2015.2948

Submitted: August 22 ${ }^{\text {nd }}, 2015$

Accepted: December $28^{\text {th }}, 2015$ 